\title{
PENSAR PARA VIVIR CON SENTIDO: UNA EQUILIBRADA LOGOMÍTICA DIALÓGICA
}

\author{
Julio López Saco \\ Universidade do Minho (Braga) - Universidad Central de Venezuela (Caracas) \\ julosa.ucv@gmail.com
}

\section{RESUMEN}

En el antiguo ordenamiento del mundo el hombre se integraba en la sociedad, pero también en los componentes que constituían el universo. Existía una empática complementariedad espíritu-temporal. Con posterioridad, el orden secular fragmentó tal unidad esencial. Un individuo deshumanizado surgió porque la razón "sustituyó" de manera inadecuada a la imaginación, provocando empobrecimiento. La desmitologización y desencantamiento del mundo por un saber tecno y antropocéntrico que se centra exclusivamente en lo racional, requiere una rehumanización, la revalorización de los saberes de una cultura del sentido. Esto se alcanza por mediación del diálogo, la conversación y el equilibrio, sin la imposición de rígidas estructuras. Muchas claves de la identidad y la razón occidentales descansan en la mitología, factor que debe motivar el reconocimiento de la presencia de impulsos míticos en nuestra cultura. Su revalorización será lo que ayude a consolidar una antropoética humanamente vinculadora con el resto de la sociedad y la naturaleza. La relación yo-tú retomaría su trasfondo afectivo y cooperante. En consecuencia, se trata de que los esencialismos sean desmadejados sin relativizar, de que se propague la relacionalidad dinámica que equilibre y armonice los opuestos: complexio oppositorum de logos y mito. En definitiva, aquellos aspectos deshumanizantes del logos y su unidireccionalidad carente de imaginación, deben asociarse con la imagen y el espectro de las emotividades humanas.

PALABRAS ClAVE: mito, razón, oposición, desmitologización, diálogo.

\section{THINKING FOR MEANINGFUL LIVING: A BALANCED DIALOGICAL LOGIC}

\section{ABSTRACT}

In the ancient order of the world, man was integrated into society, but also into the components that made up the universe. There was an empathic spirit-temporal complementarity. Later, the secular order fragmented such an essential unity. A dehumanized individual emerged because reason "substituted" in an inadequate way for imagination, causing impoverishment. The demythologization and disenchantment of the world by a techno and anthropocentric knowledge that focuses exclusively on the rational, requires a re-humanization, the revaluation of the knowledge of a culture of meaning. This is achieved through dialogue, conversation and balance, without the imposition of rigid structures. Many keys to Western identity and reason rest on mythology, a factor that should motivate the recognition of the presence 
of mythical impulses in our culture. Its revaluation will be what helps to consolidate an anthropoetics that is humanly linked to the rest of society and nature. The relationship between me and you would take on its affective and cooperative background. Consequently, it is a matter of unravelling essentialisms without relativizing them, of spreading the dynamic relationality that balances and harmonizes the opposites: complexio oppositorum of logos and myth. In short, those dehumanizing aspects of the logos and its unidirectionality lacking in imagination, must be associated with the image and the spectrum of human emotions.

KEYWORDS: myth, reason, opposition, demythologization, dialogue.

\section{INTRODUCCIÓN}

La modernidad ha tenido a bien propiciar un desarraigo, un desencantamiento (el fin aparente de lo intangible y lo mágico-espiritual), otorgando absoluta primacía al individuo y a la razón, todo ello motivado por una redimensión social de lo religioso. Tal situación ha implicado el paso desde un orden social a otro secular.

En el orden sacro, el hombre se integra en la sociedad, pero también lo hace en los componentes constitutivos del universo: en resumidas cuentas, existe una complementariedad espíritu-temporal, una suerte de empatía. En el ordenamiento secular, por el contrario, se fragmenta esa unidad cósmica por la instalación y predominio de un humanismo excluyente moderno, que excluye, valga la expresión, cualquier vínculo con lo divino, con el pasado mítico. Se resguarda, por tanto, la identidad. Comienza un nuevo hombre que parece no haber transitado por el pasado. Al final, lo que se tiene es un individuo deshumanizado que, no obstante, requiere un holismo trascendental, a pesar de la impronta avasallante del cristianismo en sus diversas formas (Gauchet, 2005: 64-70; Taylor, 2006: 77-79; Dumont, 1987: 45). El mundo de este individuo que se acaba de señalar es el del orden políticamente estructurado, el de la esfera pública y la sociedad civil.

El nuevo orden secular trata de la razón que supera el error, la superstición, la magia y el mito; pero es una razón que sustituye indebidamente a la imaginación, provocando un empobrecimiento por el carácter "reductivo" de la misma, aplicada a los mundos creados. Esta nueva "mitología", sin embargo, y en cualquier caso, no agota las formas y estructuras de las sabidurías ancestrales de las sociedades, ni tampoco el hecho de que el grupo sienta que comparte cultura, lengua, historia y religión comunes (Gellner, 2008: 25-30; Hobsbawm, 1998: 35-50 y ss.).

La secularización, desmitologización y desencantamiento del mundo arcaico de sentido, relega a éste al ámbito de lo liminar, de la marginalidad, casi de la inexistencia. Tal relegación ha sido, y es, su enfermedad, pues en ella radica el malestar de nuestra ideología ilustrada, el sobreseimiento político del sentimiento, reducido a un significado meramente funcional, olvidándose las misteriosas y oscuras religaciones míticas, simbólicas, mágicas y religiosas.

La sabiduría antigua, reconocida como cosmocéntrica y ecocéntrica, se ha visto sobrepuesta por otro saber, racional, de carácter antropocéntrico y tecnocéntrico, un tanto deshumanizante. El logos, así, ha encubierto el trasfondo sacral camuflado de ritualidad, pero estatal. Los renovados énfasis en los regionalismos imperantes, 
los acalorados debates sobre la congoja que suscitan estos tiempos modernos, la proliferación de sectas y hermandades, así como la cultura de la marginalidad, son reacciones que atestiguan un profundo malestar producido por la incontenible oleada de inhumanidad (López Saco, 2011: 367-376; Lambropoulos, 1993: 78-86).

Una rehumanización, una revalorización de los saberes escondidos y la sinceración de un mundo horizontal en un tiempo secular en donde el orden actual postfundacional procure reconocer más de un único núcleo sustancial puede, y debe, ser evocada como una necesidad imperante. La apuesta debe ser, en consecuencia, por una cultura del sentido, bajo la forma de conversación y equilibrio, y no bajo la de una estructura rígida, erigida sobre fundamentos epistemológicamente constrictores, que permita intimar con el sentido más que centrarse en demostrar verdades inmutables. Una necesaria conjugación armónica de órdenes es la propuesta de las siguientes páginas.

\section{DE LA RAZÓN AL MITO Y VICEVERSA}

La conciencia mítica configura una estructura inalienable y es un elemento de la existencia humana. Por tal motivo, deberían integrarse razón e imaginación mítica:

La conciencia mítica interviene como el hogar de las formas humanas, como el principio último de nuestras afirmaciones (...). Si la mitología es una primera metafísica, la metafísica debe ser entendida como una mitología segunda (Gusdorf, 1983: 267-268).

La alienación en el mito implica una especie de retorno a lo arcaico, mientras que la alienación en la razón supone una esterilización de los valores, un nefasto primitivismo. Hay, en consecuencia, que desmitizar y, por lo tanto, racionalizar, pero al tiempo, también hay que desracionalizar y, en consecuencia, remitizar. Tal mitización debe ser ordenada, en cuanto que acoge en sí la instancia de la razón inviscerada en el intelecto. Debe ser, entonces, una remitización crítica. La filosofía contemporánea postula ahora una antropología concreta, en la que el mito sea considerado un medio expresivo más flexible que la propia doctrina filosófica en virtud de su apertura a las influencias concretas del vivir humano. La vivencia imaginativa se da y ofrece en un estado complejo, efervescente, magmático. La función de la razón estriba en armonizarla y otorgarle coherencia, en una especie de experiencia total. De este modo, la expresión racional clarifica la vivencia mítica.

La razón puede llevar aparejada una total desmitización, que supone un vaciamiento del hombre, al quedar todo medido a través de la vara de la racionalidad matemático-científica. Así como ésta puede liberarlo de los mitos, al tiempo lo despoja de la receptividad hacia el ser, difuminándose aquello que las imágenes originales aportan a su vida. Desde tal perspectiva, el hombre estrictamente racional es completamente inhumano.

Pensar, como ver e imaginar, validan por sí mismos la aprehensión de las realidades. El perpetuo, y necesario, desplazamiento de perspectivas, así como 
un consciente compromiso de la metáfora y la imaginación, trabajan para garantizar la posibilidad de ver el conjunto, incluyendo los espacios intermedios, las bisagras que separan, de modo convencional, los niveles de realidad (Heller, 2006: 19). Al igual que las ilusiones ópticas, en las que se ven dos personas (hombre y mujer, un joven o un anciano), se pueden observar ambas imágenes simultáneamente, siendo ambas reales ( $\mathrm{y}$ necesarias). Aprehender o experimentar visualmente el conjunto requiere saltar constantemente desde una perspectiva a otra, al igual que las distintas perspectivas mito-lógicas pueden facilitar ver el conjunto de la compleja realidad.

El mito es capaz de definir los confines de la razón ofreciéndole a ésta una suerte de utilización escatológica. El aspecto creativo del mito y la lógica han sido siempre viajeros compañeros con paralelas funciones dinámicas del espíritu humano, aunque poseyendo diferentes metas y funciones. Ya la antigua filosofía griega había distinguido diversas clases de conocimiento desde el siglo VI a.C., en coexistencia armónica, como ocurrió en Heráclito o Parménides. Algunos de esos canales de conocimiento, contrastantes con el racional, eran extra-noéticos, emotivos, estéticos, místico-sacros, y se expresaban a través del arte y la religión. Se trataba de conocimientos extra lógicos, de textura unificante y emocional.

El ser humano no ha podido, en el fondo, ni debe hacerlo, excluir ninguna de sus funciones cognitivas, todas ellas valederas. Si lo hace, llega a la alienación (la del mito o la del intelecto), y se hace infiel a su propia naturaleza, aquella por la que está ubicado en el mundo. La religión, el arte o la filosofía son expresiones todas de la nostalgia humana por un paraíso perdido, que no es más que su necesaria búsqueda existencial. Aquí el mito ejerce su función pivotante esencial: con la razón (la filosofía), con la intuición estética (el arte), con la fe (en la magia y la religión) (Gusdorf, 1983: 175-177; Vitsaxis, 1991: 59-61; Evangelou, 2000: 230-231). Y es que la conciencia humana es de naturaleza unificada.

Los conocimientos de Freud y los psicólogos profundos incrementaron el sentido de que el pensamiento del hombre sobre el mundo estaba gobernado por factores no racionales que ni podía controlar ni ser completamente consciente de ellos. Desde Hume y Kant, y a través de Marx, Darwin y el propio Freud, el pensamiento humano se contempló determinado y estructurado por multitud de factores: categorías mentales innatas pero no absolutas, historia, cultura, hábitos, pertenencia social, biología, lenguaje, emociones, imaginación e inconsciente personal, lo cual llevaría a aceptar un aspecto que se entiende crucial: la imposibilidad de aprehender el orden cósmico objetivo a través de la inteligencia humana, una idea muy desarrollada por filósofos de la talla de Martin Heidegger, Bertrand Russell y Ludwig Wittgenstein, quienes hacen hincapié en la necesaria complementariedad entre la imagen y el significado literal.

Se hace imprescindible, en consecuencia, un perspectivismo radical, un poco al modo de Nietzsche (Wittgenstein, 1997: 75-80; Heidegger, 1962: sec. 79, 80; Nietzsche, 2001: 120-144 y ss.; 212-213); esto es, una pluralidad de perspectivas a través de las cuales el mundo y el hombre puedan ser interpretados y comprendidos, sin que ninguna de ellas tenga un criterio independiente autoritativo-imperativo por encima de las demás. 
El paradigma cartesiano y kantiano expresa y ratifica un estado de conciencia en el que la experiencia de una numinosa profundidad unitaria de la realidad se extingue, desencantando al mundo y aislando al hombre. No obstante, la dicotomía sujeto-objeto, constitutiva de la moderna conciencia y base de la perspectiva realística del mundo, parece enraizada, según parece demostrar la psicología profunda de los trabajos de Stanislav Grof (Hillman, 1999: 120-126), en una específica condición, proto o arquetípica de unidad, de modo que la reconciliación entre el individuo y lo universal, la racionalidad humana y el ámbito mítico del Cosmos, debe ser un objetivo primordial.

En el desarrollo de la cultura occidental, y de su historia psicológica, la tensión mítico-religiosa frente a la racionalidad, ha tenido una serie de contracorrientes (en el sentido de Heráclito): la primera, la de la reacción ilustrada contra la superstición mágico-religiosa; la segunda, la contra reacción romántica; la tercera, el auge y consolidación del materialismo filosófico y, de un tiempo a esta parte, la cuarta, el cambio, más o menos repentino, hacia el espiritualismo. Separar, y mantenerlo así, el alma (ego racional y literalidad) y espíritu (metaforización y mitismo), no es, se diría, conveniente. Por el contrario, se debe intentar desarrollar un modo "hermafrodita" de pensar (Hillman, 1985: 173-180; Harpur, 2010: 356, 364), en que ambos estén presentes, siempre y simultáneamente en todos los acontecimientos. En consecuencia, no podemos pensar o imaginar al margen de tal duplicidad.

La complementariedad la encontramos ya (como más adelante se comentará) en una falsa polaridad mito-logos. El dominio del mito retrocede ante cada conquista de la razón, pero esta acude al sendero de la primera cada vez que llega o se aproxima a sus límites más externos. En tal sentido, si la mitología se puede ver como una primaria metafísica, la metafísica sería una segunda mitología. La razón sirve a la imaginación que crea mitos, y la imaginación sirve al pensamiento que concibe (López Saco, 2005: 51-67; López Saco, 2016: 80-95). En todas las formas de civilización humana existe una unidad dentro de la diversidad, en virtud de elementos de afinidad. Así ocurre con la unidad intuitiva artística, la intelectual científica y la emocional mítico-religiosa, todas las cuales certifican, con su presencia y acción, la unidad espiritual humana.

Experiencia sensible e intelecto son indudablemente necesarios, como hace siglos señalaba Tomás de Aquino, para el conocimiento, siendo cada uno informado en el otro. No son oponentes en la búsqueda de conocimiento, sino una pareja prácticamente indisociable. El intelecto humano no puede tener acceso directo a ideas trascendentes, como ya señalaba Aristóteles y el mismo Aquino, sino que se requiere la experiencia sensorial para despertar el potencial conocimiento de universales. Así, las cosas sensibles poseen una realidad, sustancial, por sí mismas (Tarnas, 1991: 182, 353). Experiencia sensible sin intelecto activo puede ser ininteligible, pero aquella provee las imágenes particulares con las que el intelecto ilumina conceptos abstractos. El pensamiento sin sensaciones está vacío, y del mismo modo, las sensaciones sin pensamiento son ciegas. Ambos modos simultáneos e interpenetrados son necesarios para el conocimiento válido de las cosas.

Nuestra vida se manifiesta en nuestra conciencia, que descansa en el mito (conciencia de lo que es dado), que nos conduce a creer que esa nuestra conciencia 
nos manifiesta la realidad que, indudablemente, está más allá del conocimiento objetivo. El mito es, así, la expresión de una forma sui generis de conciencia. Como es lo que damos por descontado, lo que no discutimos o no es discutible, porque, además, es transparente como la luz, librándonos de tener que pensar cada cosa o aspecto, lo cual entreabre el reino de la libertad, de la libertad del ser. Pero sin la conciencia no se puede reducir a puro conocimiento de objetos, tampoco se puede hace lo propio con las simples vivencias míticas; el hombre no puede ser reducido al logos, ni la conciencia a conciencia reflexiva, por eso es necesario, imperioso, reunificar corazón-mythos y mente-logos; esto es, implicación personal y reflexión crítica (Panikkar, 2007: 21, 29-30 y 121)1.

El pluralismo, que surge del mythos, testifica la trascendencia del logos como juez único de lo real. En estas condiciones, el diálogo intercultural y la factible fecundación mutua, es posible en un plano mítico más que en uno que suponga la confrontación de logoi. Si bien el logos es prioritario en la dialéctica intracultural, el mythos posee la primacía en el diálogo intercultural. Eso significa que el ser humano tiene un modelo de inteligibilidad distinto, y válido, al conformado en el vínculo entre la evidencia racional y la rigurosa comprobación histórica, porque buena parte de las convicciones profundas humanas son interiores y habitan en el magma de lo mítico y la creencia.

El mundo mítico, esencialmente pluralístico, fue considerado opuesto a las tendencias filosóficas hacia la uniformidad y el reduccionismo, debido a que la distinción objetividad (verdad, hecho, el mundo en sí mismo) y subjetividad (opinión, valor, y respuestas humanas al mundo), fue un constructo filosófico para superar o controlar la variabilidad y la dimensión existencial del mundo vivido, sin caer en cuenta de la necesaria coexistencia pluralística de verdades, que no implica ni la objetivización del mito ni la subjetivización de la racionalidad. La estricta distinción entre sujeto y objeto es hoy ya una escasa garantía frente a la naturaleza correlativa y a la inseparabilidad de los componentes del mundo y del propio ser humano. Se debería, quizá, hablar entonces de un pluralismo objetivo que indique la legitimidad de los diferentes modos de revelación del mundo, que deben coexistir.

Con la ciencia, la situación ha sido análoga. Esta ha tenido la tendencia a convertir lo profano, frente a lo sacro, en el único estándar de inteligibilidad. La diferencia respecto al mito es su énfasis sobre ciertos elementos del mundo, de modo que ambos, ciencia y mito, no representan, en realidad diferentes mundos en competencia, sino modos de revelar un mundo multidimensional. La tendencia científica ha radicalizado las cosas, desarrollando la segregación de ciertos aspectos de la cultura, o juzgando elementos sacros de acuerdo a estándares profanos, un factor clave que

${ }^{1}$ La historia mítica es la forma o el revestimiento con el que el mito es expresado e iluminado. Recuérdese que el mito no se puede ver en retrospectiva; cuando lo vemos, lo hacemos, generalmente, en las trazas del logos, de ahí su "intimidad". 
significa que la ciencia no fue un gradual descubrimiento de la verdad, sino un paulatino desvelamiento de la ciencia misma (Hatab, 1990: 308-309; 326; Snell, 1960: cap. 10) ${ }^{2}$. Así pues, la tendencia a que el mito sea desplazado por la ciencia no es, ni puede, ni debe ser, una condición del pensamiento científico, pues un científico que se precie debe reconocer los límites de la indagación y del método mismo.

Esta tendencia fue una consecuencia de una metafísica que urgió al pensamiento occidental desde Platón en adelante a asumir la verdad como absoluta o uniforme, asunción que, como es evidente, conllevó una uniformidad exclusivista que condujo a un reduccionismo hoy absolutamente inapropiado.

Los relatos racionales del mundo retienen fundamentos significativos y significantes de la revelación mítica. Ese vínculo no querido entre razón y mito puede resolver los perennes problemas filosóficos creados por las asunciones metafísicas, reduccionistas y racionalistas. De hecho, si la naturaleza de la filosofía muestra conexiones con el mito entonces los antagonismos tradicionales entre ambos solamente son un retrato de una clase de auto alienación y auto distorsión dentro de la filosofía que ella misma debe superar.

\section{IMAGINACIÓN Y MITO EN LAS REALIDADES}

La realidad es, sin duda, muy compleja. Lo imaginario (irracional, sensible y subjetivo), es esencial en la construcción de realidades y en la institucionalización de las prácticas, interrelacionándose con lo racional. El imaginario mítico espolea la creación de nuevas formas culturales, religioso-simbólicas, míticas y estéticas, y revivifica los imaginarios sociales constituidos que están solidificados, fosilizados. En todo caso, la sociedad humana no se debe instalar en un estado de creación pura ni tampoco en otro de represión inhibidora de lo mítico, un hecho que supone la ineludible necesidad de rechazar el dogmatismo clásico de lo único (Castoriadis, 1983: 230-231 y ss.).

Los componentes no racionales están impresos en las experiencias individuales y sociales. Lo imaginario, que implica un fondo de creatividad de tintes casi trascendentes, supone un sustrato antropológico ligado a la creatividad, inventiva y la alteridad, un fondo común (esencia), transhistórico, del que brotan construcciones concretas de la vida colectiva. En tal sentido, deben ser relegadas las asociaciones al uso, que identifican a la sociedad institucionalizada con el ordenamiento, y a los componentes mítico-imaginarios con las fuerzas del caos y el desorden. El ser humano, por consiguiente, no es exclusivamente racional y calculador, ni puramente pasional, sino que continuamente se crea y re inventa, siendo auténtica potencialidad.

${ }^{2}$ El empleo genérico del artículo definido ha sido considerado en la lengua griega como un referente al potencial de abstracción que se encontraba en el lenguaje arcaico. El dinamismo verbal se rindió a la claridad y precisión del sustantivo en esa tarea científica de particularizar lo universal. 
Escribimos paulatinamente nuestra propia narración desde imágenes que simbólicamente aglutinan los diversos aspectos de lo social e individual. El mito conforma la imaginación social, que funciona dialécticamente entre utopía e ideología, ambas en él contenidas (Ricoeur, 1986: 266-267 y 310-312). La primera, mantiene la vitalidad del grupo, en tanto que la segunda, la necesaria condición de la integración, con el fin último de preservar el orden. La utopía previene a la ideología de llegar a convertirse en un sistema claustrofóbico, mientras que la ideología previene a la primera de llegar a ser una fantasía huera, vacía. Por eso, ambas requieren un posicionamiento equilibrado.

El mito, perennemente presente en la sociedad humana y su cultura, está activo en las civilizaciones arcaicas, pero también pervive en la actualidad bajo una capa conceptualista, funcionalista y de completa trivialización icónica mass-mediática. En algunas ocasiones, estos recursos míticos escondidos estallan en movimientos sociales novedosos o en revoluciones utópicas de escasa duración, como fue el mayo francés de 1968, o se actualizan personificándose en ciertos roles, desmitologizándose después en racionalizaciones, en un proceso repetitivo siempre continuado.

Cuando la razón, la lógica experimental, desmitologiza, incurre en una propia auto-mitificación, donde el mito se convierte en ilustración, en algo cercano a una ideología, que proporciona sentido a una sociedad histórica pero que también puede torcer peligrosamente la realidad (Horkheimer, 1973: 184-185; Mardones, 2000: 141-142, sobre el perfil mítico, latente en ideologías como el comunismo, el nacionalsocialismo hitleriano y el neoliberalismo; Adorno, 1992, sobre la falsa desmitologización de las sociedades). De esta manera, ciertos aspectos de los mitos del origen o fin del mundo y de la humanidad, protológicos y escatológicos, alimentaron ideologías, en especial cuando una sociedad y su cultura se hallaron en crisis e intentaron volver la mirada hacia fuentes originales buscando recrear un nuevo mito que se entendiese aplicable a esa actualidad. El mito impregna, así, la sociedad al completo. No sería comprensible el ritualismo social, que provoca comportamientos y actitudes concretas, sin el latir mítico-religioso, herramienta imprescindible para comprender aspectos singulares y profundos de una civilización.

Las concepciones del mundo, con sus trasfondos míticos, no son evadidas ni por el rigorismo científico. La ciencia, como la historia, se asienta en la realidad socio-cultural humana, y sus artífices son hombres, con ilusiones y creencias, en cuyas formulaciones y descubrimientos lo intuitivo e imaginativo y hasta lo metafórico, juegan un papel imprescindible. Incluso el mundo de la ciencia, como algunos estudiosos han sugerido (Mardones, 2000: 163-164), puede constituir una "nueva mitología”, en concreto en relación a teorizaciones globales que pretenden alcanzar y asentar una teoría certera de indesmontable final, y al respecto de consideraciones teóricas que vinculan opiniones científicas con las cosmovisiones religiosas, en muchos casos, de culturas orientales.

El ser humano siempre se ha movido entre las afirmaciones incontroladas e incontrolables, las certezas supramundanas indiscutibles, el ámbito de procesos establecidos inductiva y deductivamente y la superación racional de la duda; es decir, entre dos polos que requieren de perfecta integración por el bien de la salud mental y física humana, el de su capacidad mítica y lógica, cuya dialéctica "antitética", que 
implica figura-realidad, superstición-ciencia, experientia-experimentum, religiones positivas-religión natural, o simplemente, romanticismo e ilustración es, en realidad, superable en su conjunción y no por la reducción de uno al otro: ni la racionalización autoritaria que puede crear dictaduras burocráticas y fuertes "mitologizaciones", ni lo ilimitado de la existencia mítica, que puede desembocar en terribles irracionalismos inhumanos de consecuencias devastadoras.

En todo instante es percibible una presencia y ciertos comportamientos míticos en la praxis científica, así como un particular carácter racionalizador-cientifista en el marco de la cotidianidad mítica. Quizá se debería asimilar que las representaciones mito-poéticas no están allende los límites de la razón, sino más allá del ámbito de la autoconciencia de lo absoluto, como ya Hegel había señalado (referencia en Duch, 1998: 40-50 y ss.).

El proceso racional del ser humano siempre ha sido contemplado desde un ángulo evolutivo de movimiento ascensional, que condujo de la magia al mito, y de aquí, a la religión organizada, la filosofía, la historia y la ciencia, culmen definitivo. Si aplicamos la óptica explicativa lógico-empírica no se negará un "progreso" desde el pensamiento mágico y mítico-religioso al racional-filosófico y científico (Berger - Luckmann, 1974: 122-123 y ss.; Armstrong, 2005: 103 y ss.; López Saco, 2011: 369). Sin embargo, tampoco se debe descartar la contemplación de un singular movimiento descendente paralelo al anterior, desde la magia a la ciencia, respecto a la lógica relacional y la capacidad integradora y sintética de todo con todo, de modo que, a la par que se ha ido "ganando" en objetividad científica y análisis, se ha ido "perdiendo" relacionalidad (algo muy palpable, por ejemplo, en la más o menos mecanicista correlatividad cosmológica del pensamiento de la antigua China), coimplicación y síntesis de sentido, aspectos todos ellos exponenciales en el mito. Debemos ser partícipes, por consiguiente, de la complementariedad necesaria de los dos modos de racionalidad presentes en el pensamiento humano a la hora de evaluar y articular la realidad, y no de una visión excluyente, dualista e incluso jerárquica.

$\mathrm{Al}$ igual que el pensamiento lógico más riguroso proporciona una óptica objetiva de la realidad, aunque con frialdad ontológica, las perspectivas míticas, a través del simbolismo vinculador con el todo, nos conectan con el sustrato imaginal y transconsciente (en el sentido de los hermeneutas simbólicos), arquetípico, si bien limitando la distancia crítica que señalan las máscaras de la realidad secular. El funcionamiento real de la cultura y la creatividad no permite separar parcelas finitas de significado, por lo que debemos ser conscientes del imprescindible mestizaje mítico-racional: a la racionalidad analítica, que fragmenta los fenómenos y cuestiones básicas en elementos, y está lejos de crear unidad y vinculación valorativa de sentido, debemos unir el potencial socializador y relacionador de la sintética mítica.

Mythos y logos deben imbricarse en una coincidencia de opuestos que elimine las ilustraciones unilaterales y equilibre las racionalidades. Uno y otro, como expresiones diferentes pero complementarias, necesarias para descubrir y describir al hombre y sus acciones, conforman lenguajes usados para conocer la realidad y relacionarse con ella, convirtiéndose en fundamentos existenciales. La relación comunicativa y la alteridad se conjugan como elementos esenciales en el conocimiento del mundo 
(escasez comunicativa de las sociedades actuales y necesaria presencia de inspiración e imaginación humana, Steiner, 1991: 75-78; López Saco, 2016: 88-89 y ss.), realidad que hay que ver desde diversas ópticas que puedan cubrir el amplio espectro de posibilidades que muestra un orbe complejo y un hombre multifacético. Logos y mythos son expresiones básicas de la capacidad humana de apalabramiento, palabras griegas polifónicas, con intersubjetividad, necesarias para la armonía psicológica y espiritual del hombre. Todas las dicciones humanas son útiles en su expresión de aspectos de la humanidad, acercamientos no jerarquizables para evitar discursos totalizadores y omniexplicativos y los riesgos de la incomprensión y la agresividad.

El uso disciplinado y metódico de la razón cartesiana había desbancado la preconcepción de lo antiguo, de lo clásico, como autoridad, puesto que se creía que la razón o sentido razonable todo lo resolvía, ejerciendo, de este modo, una autoridad dogmatizada, otorgada, de ciega obediencia. No obstante, como ya se ha venido aludiendo, más allá del marco racional están presentes verdades desligables de la razón, como el saber moral, donde el ser humano es observado como el ser que actúa, no como comprobación de lo que es; el estético, así como sentidos ocultos ${ }^{3}$, otra "autoridad", en sentido gadameriano (Gadamer, 1993: 344-349 y ss.), que puede mediar con el logos, que es la tradición anónima, cuya influencia es más que notable sobre nuestros actos. El conocimiento estético y el saber ético-moral son experiencias humanas, (como la comprensión previa de M. Heidegger), anteriores y externas a aquellas metódicas y técnico-instrumentales, tan relevantes como el propio conocimiento empírico .

Aquello que siempre hemos vislumbrado como humanístico ha quedado sometido, por regla general, a lo metódico, aunque las experiencias estéticas, poéticas, imaginales, míticas, insinuadoras e implicativas, son modos de conocimiento primario, originario, legítimo y válido.

Pensar por medio de imágenes, fruto del ahistoricismo humano, precede al lenguaje y a la razón discursiva, revelando formas de la realidad impenetrables a otros mecanismos de conocimiento y expresión (Serrano Poncela, 1974: 23; Eliade, 1989: 2-10 y ss.) $)^{5}$, y mostrando una amplitud bastante superior a los, a veces, extenuantes, límites verbales del lenguaje teórico por su indefinición y multivalencia.

${ }^{3}$ El develamiento del sentido axiológico de las cosas, escondido a la visión directa, se logra transversalmente a través de la imagen, la metáfora, el símbolo, el mito.

${ }^{4}$ Se implica, así, un saber anterior a la ciencia, precedida por aspectos que la posibilitan, la filosofía o la historia: el saber cosmo y ecocéntrico, que es sobre-impuesto por otro antropocéntrico y tecnocéntrico. Existe, pues, un sentido, un "alma” de las cosas, factor que no debe impedirnos una imbricación concepto-imagen, logos-mythos o significado-sentido.

${ }^{5} \mathrm{La}$ indefinición, rasgo caótico, parece incomodar un tanto al humano que desea, con un lenguaje instrumental preciso, dominar, definir y limitar para comprender y también para dominar. 


\section{POLARIZANTE OPOSICIÓN CONSTRUCTIVA}

Muy por encima de compartimentaciones innecesarias e inútiles, se puede, y se debe, por consiguiente, establecer una logo-mítica o razón mito-lógica: el mito, como impresión onto-simbólica de lo real, representa ya una primera racionalización de lo irracional, pues el relato mítico correlaciona los elementos caóticos de las experiencias primarias de la vida. La experiencia mítica, vertida en la religión o el arte, logra vehicular correspondencias y correlaciones suficientes como para organizar configuraciones de sentido profundas, estructuras subjetivas que alcanzan objetividad para la especie humana al sintetizar motivos universales, o transculturales, y patrones básicos de aprehensión del mundo y la naturaleza (Durand, 1981: 362-370 y ss.; Ortiz-Osés - Lanceros, 1997: 249 y ss.; Jung, 1988: 66-67 y ss.; Caro Baroja, 1991: 24-25 y ss., arquetipo como modelo común, como exemplar primigenium) ${ }^{6}$.

Tras el logos racional está soterrado un mito "injertado": en el funcionamiento operativo y cuantitativo del logos racional-científico se llega a ciertos "límites" que bordean lo cualitativo; es decir, la verdad y la explicación racional del mismo choca con el sentido y su implicación onto-relacional, como parece hoy muy claro en la física cuántica, en la que el logos científico, racional y empírico, prácticamente accede a una cosmovisión casi mítica. De este modo, por consiguiente, entre mito-irracionalidad (a-racionalidad o extra-racionalidad) y logos-racionalidad, existe un inter-lenguaje hermenéutico mediador de los contrarios, como el filosófico, con su razón analógica situada entre la equivocidad del mito y la única voz del logos racionalista, que es paradigma de la dialogía intersubjetiva entre sentido y verdad

${ }^{6}$ Los "arquetipos", imágenes fundamentales, son matrices de los patrones de comprensión humanos que permanecen como urdimbres originarias que subyacen en nuestras estructuras de pensamiento. En su nivel más profundo presentan una estructura básica y configuradora de la psique humana. Como estructuras del imaginario simbólico son, se podría decir, símbolos radicales propios de nuestra "ausencia de consciencia cultural", generalmente reprimidos o arrinconados por nuestra consciencia colectiva, nuestra racionalidad cotidiana. En su textura implicativa son ideas de la voluntad e imágenes primordiales consteladoras de sentido, que proviene de la mezcla de sentir y pensar. Se conforman, así, como las condiciones de nuestras dicciones, el mito del logos y la precomprensión de la comprensión. El imaginario arquetípico (si se quiere prototípico), mito-simbólico, de orientación ontológicotrascendental, es una reinterpretación del inconsciente colectivo jungiano, según el cual la ontologicidad del lenguaje gadameriano se reconvierte en la ontologicidad del lenguaje imaginal, y la realidad se constituye como configuración energética y resurge como refiguración humana. Las distintas imágenes de los "arquetipos", respecto al papel psico-social del individuo o a las etapas socio-históricas de la humanidad, en función de lo cual "la historia no sería más que una realización simbólica de las aspiraciones arquetípicas frustradas", y las proyecciones imaginarias y míticas entrarían paulatinamente en imitaciones activas, en formas de vida que se codifican en conceptos socializados y en sistemas pedagógicos, han sido tratadas por estudiosos como Durand. La razón y la inteligencia, lejos de estar aisladas del mito a través de un progresivo proceso de maduración, únicamente conforman puntos de vista más abstractos, y más especificados por el contexto socio-histórico, de la corriente de pensamiento fantástico que vehicula los "arquetipos". 
(significado), entre mito-símbolo y logos-signo. Esto quiere decir que, como seres humanos, podemos indagar tanto el sentido de la verdad (implicación de la explicación), como la verdad del sentido (explicación de la implicación), superando, así, la separación, sobre todo del pensar occidental, del sentido (mito) y la verdad (razón), que en el mundo oriental suelen aparecer más o menos confundidos, mezclados.

Así pues, la "razón mitológica", la complementariedad "logo-mítica", revela la significación antropológica y cosmológica plena, como un lenguaje fratrial (Ortiz-Osés - Lanceros, 1997: 304-305; Detienne, 1985: 75-76 y ss., equiparación entre poetas y filósofos en la Grecia de la antigüedad; Bermejo Barrera, 1994: 69-89, sobre el distanciamiento temporal y social de la palabra mítica del poeta respecto a la racional del filósofo) ${ }^{7}$ que se sitúa entre el mito, como lenguaje maternal, y el logos abstracto como lengua paterna. La comprensión de tal unión deja de lado el establecimiento de etapas, mítica y lógica, sucesivas, por una simbiosis entre ambos, del mismo modo que pensar y hablar no se pueden separar, puesto que conviven en la persona y son manifestación sincrónica y diacrónica del ser a la vez.

El mito, inherentemente humano y penetrado de ambigüedad, requiere, sin duda, la vigilancia crítica del logos, pero ello no significa invalidarlo como irracional o tildarlo de infantil, arcaico y salvaje, como ha ocurrido en buena parte de la historiografía sobre el tema. No se olvide, una vez más, que no hay una única razón, pues esta se manifiesta en una pluralidad de dimensiones, que el pensamiento mito-simbólico es fundamento de la condición de hombre y que el horizonte vital humano sobre el que se eleva el entramado institucional y de pensamiento descansa en el ámbito de la creencia y la confianza.

En nuestro marco socio-cultural actual podemos creer que la ausencia del mito es la de un guía, modelo o referente que ofrezca sentido, en especial para una juventud ahogada en un individualismo desmotivante, vacío y frívolo, pero también que esta es una época apta para la proliferación y el abuso de nuevas mitologías que respondan, muy desorientadoramente, a las necesidades de sentido vital, en específico, de esa misma juventud. Esta suerte de paradoja sólo se supera asumiendo que el mito, como acompañante de la racionalidad de lo funcional, crítico e interpretativo, es uno y lo mismo que la razón, con lo que se puede evitar la presencia y consolidación de poderosas fuerzas ilustradoras unilaterales que tiendan a la totalitaridad.

${ }^{7}$ Esta "hermandad" mito-lógica se ha hecho históricamente difícil en Occidente. La cultura oral, propia del mito, integra los niveles de conocimientos interrelacionando hechos, factor que motiva que el saber oral aparezca como una totalidad. Bajo el predominio de la civilización de la escritura, propia de la filosofía, se diferencian y sistematizan esos saberes, codificándolos, separándolos y perdiéndose, así, la visión holística del mundo. La tendencia, occidental y primordialmente europea, a estudiar pensamientos arcaicos tomando como referencia el modo de reflexión filosófico ha propiciado las incomprensiones del pensamiento mítico y su devaluación, sin caer en la cuenta de que para que existieran "filósofos" tuvo que haber, previamente, poetas. 
La autoridad que deriva de la razón, y que supone conocimiento racional absoluto, no es opuesto, radical, irreductible e incondicionalmente, a aquella que deriva de la tradición, como poder anónimo del pasado no fundamentado racionalmente, pues con el acto de reconocimiento y de conocimiento se conjuga el poder de lo transmitido, que ejerce influencia en nuestras acciones y modos de comportarnos. El pensamiento humano está lleno de situaciones que la razón científico-matemática e instrumental no llega a abarcar, lo que supone que la realidad es "infinita" y muchos aspectos no son conocibles. Para algunos de ellos la "experiencia humana", con sus elementos intuitivos, imaginativos, míticos, procura acercamientos no medibles que se hacen tan útiles como los que alcanza a hacer comprensibles la razón (Gadamer, 1993: 347-348; Gadamer, 1994: 89-112).

La complexio oppositorum de logos y mito, su ponderado equilibrio, moldea el verdadero progreso humano y permite a la humanidad enfrentar con garantías las contingencias vitales propias del mundo y del hombre: lo deshumanizante del logos y su carácter de única direccionalidad, falto de imaginación, debe, en definitiva, y sin duda, acompañarse de la imagen y el espectro de la emotividad humanas. Un buen ejemplo de mediación entre el logos-razón y el mythos-corazón en diálogo, sintetizando el mito "pre lógico" y el logos racional, el pasado mítico y el futuro lógico, en una dialéctica de hermandad, ha sido la figura del Cristo neotestamentario.

En la postmodernidad, ecumenismo fundamentado en la interculturalidad formada por el pluralismo dialéctico de los opuestos (Ortiz-Osés, 2001: 38-39 y ss.; Ortiz-Osés, 2003: 188-204; López Saco, 2005: 54-55), logos y mythos deben proyectar un mito-logos que asegure la apertura universal y su contrapunto simbólicoromántico de lo diferencial. La razón, la verdad abstracta (desnudamiento asimbólico, esclarecimiento exotérico explicativo), es complementada por la mito-simbólica del sentido (revestimiento afectivo, auscultamiento esotérico implicativo), como referente esencial de la coimplicidad simbólica de los contrarios. La pareja mito-razón, como materia-forma, deben cundir en un auténtico hiero gamos, un emparejamiento simbólico, diluyendo, o borrando así, cualquier dicotomía absolutizada.

Frente al criticismo es necesario, por consiguiente, el sentido de revelación o transfiguración de lo mítico, lo simbólico sacro, lo artístico o lo religioso, aunque siempre sin dogmatismos. Esencialismos y sustancialismos deben ser desmadejados sin optar por el relativismo, sino por la relacionalidad dinámica que armonice, equilibrándolos, los opuestos. Entre la clásica fundamentación onto-racionalista y la desfundamentación postmoderna, puede, y debe caber, una fundamentación anti-fundamentalista, no exclusivista: aquella imaginaria.

El espíritu humano es el fondo de una conjunción entre mundo míticosimbólico, generalmente inhibido o escondido, y su manifestación racional, cuyo horizonte ideal es la síntesis razón y mito o razón y simbolismo, en una especie de pensamiento integrativo (Maffesoli, conferencia, 29/10/2006); es decir, que retrocede e integra, no progresivo (que va hacia algún lugar y que supone un modelo lineal), gráficamente representado en una topología espiriliforme. En ese retroceso se vuelve al vientre, al sentido que surge de la vagina, no del falo masculino, de modo que la fantasía-femenina primigenia acaba fecundando la razón masculina posterior, conformando un todo unitario y conjunto. Únicamente teniendo presente 
esta necesaria y armónica relacionalidad seremos capaces de entendernos en nuestra justa medida y valorar, con mayor objetividad, los aconteceres históricos de los que somos agentes y actores principales.

Si nos abocamos a penetrar, finalmente, hacia el subsuelo de la cultura humana es muy probable que podamos alcanzar un estrato ideológico constituido por modelos cognitivos, conductuales y emocionales comunes a todos los seres humanos. Esa atávica "herencia", en donde el mito está profundamente enraizado, y que nunca abandonará a la humanidad, por ser propio de la misma, debe siempre tenerse en cuenta a la hora de establecer una síntesis integradora con el pensamiento lógico y racional, de modo que, así, podamos comprendernos mejor como seres y como agentes de nuestros actos en el marco de la naturaleza que nos rodea y acoge.

\section{CONCLUSIONES}

El mito emplea un proto-lenguaje equívoco, anfibólico, maternal, que se dirige hacia el sentido, busca la veracidad a partir de símbolos pre-lingüísticos, mira de frente a la trascendencia mediante la creencia, y se encierra en la doxa, la intuición, la evocación y el mundo vital experimental, mientras que el logos usa el metalenguaje unívoco, patriarcal, buscando el significado, advirtiendo la verificación en los signos postlingüísticos, observando la realidad y a lo inmanente a través del saber, e imbricándose en la razón y la conceptuación.

Se ha defendido aquí que a través de una hermenéutica implicativa, de intersección, al modo de la armonía de los contrarios pitagórica, el dia-logos debe primar: la significación, la mirada a lo trascendental por mediación de la sabiduría, y la reflexión y el entendimiento del mundo y el ser humano. Se sabe que los mitos no se definen como sustancia objetiva que existe fuera o aparte de quien los creó. Su categorización o teorización es una ilusión, o un constructo moderno, usado al servicio de programas que reivindican trascender los mitos primitivos, como la ciencia o la misma historia. El mito es en función de para qué es o sirve, no necesariamente por ciertas cualidades narrativas particulares: en su variabilidad estriba su generación y perpetuación continuada, persistente e inmortal.

La idea, muy extendida y no verdaderamente acertada en su resolución, del contraste entre naturaleza-salvajismo, y cultura-civilización, no deja de ser, en el fondo, un elemento (mítico) de configuración de la identidad propia: la del Occidente culto. Cierta claves de la identidad, y de la propia razón occidentales, radican en la mitología, lo que debería impulsarnos a reconocer la presencia de impulsos míticos en el seno de nuestra cultura (Bartra, 1996: 218 y 305-306; Duerr, 1988: 16-25; Midgley, 2011: 150; Morin, 1994: 15-16 y ss.). En tal sentido, se podría decir que el mito está en uno mismo y nos ayuda a entendernos. Así pues, la revalorización del mito es, o debe ser, hoy la premisa esencial que ayude a sustentar y a consolidar una suerte de antropoética íntima y humanamente vinculadora con los demás miembros de la sociedad, con la naturaleza y el cosmos. De este modo, la directa e íntima relación yo-tú retomaría su trasfondo emotivo-afectivo y de cooperación.

El sentir humano siempre incorpora pensamientos, aunque no sean completamente articulados, en tanto que ciertas razones se pueden ofrecer en respuesta 
a particulares conjuntos de sentimientos y evocaciones. Cuando se juzga algo erróneo, algunos sentimientos acompañan tal juicio, mientras que las evocaciones e intuiciones pueden ser complementadas por pensamientos que analicen sus significados y los articulen de una manera tal que genere coherencia o estándares útiles.

Los mitos indican calladamente las transmisiones y los límites sustanciales que la realidad plasma y ofrece. La conciencia formalizadora y tecnificada apenas lo comprende, factor que es indicativo de la necesidad de inmiscuirse afectivamente dentro de lo mítico, dejándose informar por los mitos (Geertz, 2003: 81 y nota 70; Young, 1990: 34; Cencillo, 1970: 447-448 y ss.). La simbología cultural propia de los ámbitos afectivo e intelectivo de la menta humana son distintos: la ritualidad, la estética o el mito, por un lado, mientras que por el otro el lenguaje discursivo y las prácticas experimentales. Sin embargo, tales diferencias no lo son en un sentido profundo; sólo funcionalmente, no sustancialmente, pues las ciencias poseen sus empleos afectivos y evocativos, y la poesía, por ejemplo, sus usos intelectuales. Se desprende de aquí, por lo tanto, que la religiosidad y el mito son elementos necesarios para la realización existencial del ser humano.

La verdadera sabiduría, en fin, debe consistir en la aceptación, no la supresión, de las contradicciones y contrastes, de las paradojas, los dilemas, que son propios de la naturaleza auténticamente compleja del ser humano. Hay más de una razón, razones que van más allá de la razón clásica. Lo que se debe oponer a un déspota saber racional establecido desde hace mucho es una razón distinta, plural. Reconocer la presencia de otras lógicas imbricadas con la razón, así como sus límites propios, podría limitar el despotismo y el dogmatismo de la racionalidad ilustrada heredada, cuya validez "universal" se enraizó en la hegemonía política europea, la tradición colonialista y en la dominación económica capitalista, en una época que se creía ya periclitada o, al menos, en franca regresión.

\section{REFERENCIAS BIBLIOGRÁFICAS}

Adorno, T. W. (1992): Dialéctica negativa, Taurus, Madrid.

ARMSTRONG, K. (2005): Breve historia del mito, Salamandra, Navarra.

BARTRA, R. (1996): El salvaje en el espejo, Destino, Barcelona.

Berger, P. - Luckmann, T. (1974): La construcción social de la realidad, Amorrortu, Buenos Aires.

Bermejo Barrera, J. C. (1994): Entre Historia y Filosofía, Akal, Madrid.

Caro Baroja, J. (1991): De los Arquetipos y Leyendas, Istmo, Madrid.

CASTORIADIS, C. (1983): La institución imaginaria de la sociedad, Tusquets, Barcelona.

Cencillo, L. (1970): Mito. Semántica y Realidad, B.A.C., Madrid.

Detienne, M. (1985): Los maestros de la verdad en la Grecia Antigua, Taurus, Madrid.

DuCH, LL. (1998): Mito, interpretación y Cultura, Herder, Barcelona.

Duerr, H. P. (1988): Nacktheit und Scham. Der Mythos von Zivilisationprocess, Suhrkamp, Frankfurt.

Dumont, L. (1987): Ensayos sobre el individualismo, Alianza, Madrid. 
DURAND, G. (1981): Las estructuras antropológicas de lo imaginario. Una introducción a la arquetipología general, Taurus, Madrid.

ElIADE, M. (1989): Imágenes y símbolos. Ensayos sobre el simbolismo mágico-religioso, Taurus, Madrid.

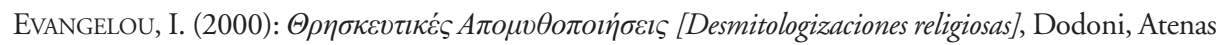
$\&$ Ioannina.

Gadamer, H.-G. (1993): Verdad y Método. I. Fundamentos de una hermenéutica filosófica, Sígueme, Salamanca.

Gadamer, H.-G. (1994): “Los fundamentos filosóficos del siglo XX”, en VATtimo, G. (dir.), La secularización de la filosofia: hermenéutica y posmodernidad, Gedisa, Barcelona, pp. 89-112.

Gauchet, M. (2005): El desencantamiento del mundo, Trotta, Madrid.

GEERTZ, C. (2003): La interpretación de las culturas, Gedisa, Barcelona.

Gellner, E. (2008): Naciones y nacionalismos, Alianza, Madrid.

Gusdorf, G. (1983): Mythe et metaphysique, Flammarion, París.

Harpur, P. (2010): El fuego secreto de los filósofos, Atalanta, Girona.

Hatab, L. J. (1990): Myth and Philosophy. A Contest of Truths, Open Court, Chicago.

Heidegger, M. (1962): Being and Time, Harper \& Row, Nueva York [Trad. Esp. Ser y tiempo, Trotta, Madrid, 2012].

Heller, S. (2006): The Absence of Myth, State University of New York Press, Albany.

Hillman, J. (1985): Anima: an Anatomy of a Personified Notion, Spring Publications, Dallas.

Hillman, J. (1999): Re-imaginar la psicología, Siruela, Madrid.

Hobsbawm, E. (1998): Naciones y nacionalismo desde 1780, Crítica, Barcelona.

Horkheimer, M. (1973): Crítica de la razón instrumental, Sur, Buenos Aires [Trotta, Madrid, 2002].

JunG, C. G. (1988): Arquetipos y sentido, Universidad de Deusto, Bilbao.

Lambropoulos, V. (1993): The Rise of Eurocentrism: Anatomy of Interpretation, Princeton University Press, Princeton.

LÓpez SACO, J. (2005): “Una logomítica de la complementariedad. Reflexiones teórico-culturales acerca de las relaciones del mito, la historia y la filosofía", Extramuros 22: 51-67.

LÓPEZ SACO, J. (2011): "Síntomas de enfermedad en la cultura occidental: el síndrome del otro y el mito del progreso", Revista Presente y Pasado 16 (32): 367-376.

LÓPEZ SACO, J. (2016): "El movimiento pendular mythos-logos: hacia una dialéctica comprensiva mito-lógica", Revista Praesentia 17: 80-95 [http://erevistas.saber.ula.ve/praesentia].

MAfFesoli, M. (2006): "Invaginaçâo do sentido", conferencia dictada el 29 de octubre del 2006 en el XIV Ciclo de Estudos sobre o Imaginário. As Dimensôes imaginárias da Natureza, celebrado en Recife, Brasil.

Mardones, J. M. (2000): El retorno del mito. La racionalidad mito-simbólica, Síntesis, Madrid.

Midgley, M. (2011): The Myths We Live By, Routledge, Londres.

MORIN, E. (1994): Para salir del siglo XX, Kairós, Barcelona.

Nietzsche, F. (2001): La gaya ciencia, Akal, Madrid.

Ortiz-OsÉs, A. (2001): “Mitologías culturales”, en SOlARES, B. (ed.), Los lenguajes del símbolo, Anthropos, Barcelona, pp. 34-63. 
Ortiz-Osés, A. (2003): Amor y sentido. Una hermenéutica simbólica, Anthropos, Barcelona.

Ortiz-Osés, A. - Lanceros, P. (dirs.) (1997): Diccionario de Hermenéutica, Universidad de Deusto, Bilbao.

PanikKar, R. (2007): Mito, fe y Hermenéutica, Herder, Barcelona.

Ricoeur, P. (1986): Lectures on Ideology and Utopia, Columbia University Press, Nueva York.

Serrano Poncela, S. (1974): Formas Simbólicas de la Imaginación, Equinoccio - USB, Caracas.

Snell, B. (1960): The Discovery of the Mind, Harper \& Row, Nueva York.

SteIner, G. (1991): Presencias reales. ¿Hay algo en lo que decimos?, Destino, Barcelona.

TARnas, R. (1991): The Passion of the Western Mind, Ballantine Books-Random House, Nueva York [Trad. Esp. La pasión de la mente occidental, Atalanta, Girona, 2008].

TAYLOR, CH. (2006): Imaginarios sociales modernos, Paidós, Barcelona.

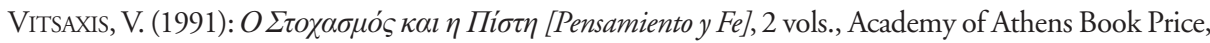
Hestia, Atenas [En ese año el autor ganó el Premio de la Academia de Atenas por esta obra].

Wittgenstein, L. (1987): Tractatus Lógico-philosophicus, Alianza, Madrid.

Young, R. (1990): White Mythologies: Writing History and the West, Routledge, Londres. 
